\title{
Penile fracture caused by wild bear attack
}

\author{
A.Agarwal ${ }^{1}$, S.R. KC ${ }^{2}$, P.Shrestha ${ }^{2}$, S.Hirachan ${ }^{2}$, W.K.Belokar ${ }^{3}$ \\ ${ }^{1}$ Mch Resident ${ }^{3}$ Professor and Head, Department of Urology, ${ }^{2}$ Resident, Department of Surgery, CMS-TH Bharatpur, \\ Nepal
}

\begin{abstract}
Interaction between humans and wild animals has increased in recent times because of overlap of habitats. A proportion of this interaction is violent. Usually a large wild animal, like bear, causes significant bony trauma or attacks upper torso of body. We herein present a case of Asiatic black bear attack on an unusual part of body in a 40-year-old man near Nawalparasi, Nepal. The beast attacked genital region causing penile fracture. Patient was managed successfully in three stages.
\end{abstract}

Key words: Animal attack, black bear, penile fracture.

\section{Introduction}

Interaction between humans and wild animals has increased in recent times, because of overlap of habitats. A proportion of this interaction is violent. Most of the literature describing the injuries sustained by humans in such contact pertains to the involvement of soft tissues. Trauma to bones and joints is only witnessed when larger animals attack humans. We report an unusual case of penile fracture with avulsion injury on right groin and anterior abdominal wall due to attack by the Asian black bear (Ursus thibetanus).

\section{Case report}

A 40-year-old gentleman was attacked by a black bear while hiking alone in a remote wilderness area near Danda, Nawalparasi (Nepal). The man was going for fishing at 14 hours in Narayani river. The bear, apparently unprovoked, rapidly approached the man and attacked him. Sudden and heavy push Correspondence: A.Agarwal E-mail: draaman@gmail.com made him to fall on the ground and the bear proceeded to bite his anterior abdominal wall and genitalia. The patient also sustained superficial scratches to the abdomen from the animal's claws. The bear stopped when he saw local people came running towards him after hearing the scream of injured man. Injured man was still conscious, however during transport by ambulance to the Emergency Department, he lost his consciousness.

Upon arrival, the patient's vital signs were unstable. He was unconscious and actively bleeding from anterior abdominal wall and genitalia. His blood pressure was 70/50mm of $\mathrm{Hg}$ and pulse was weak and thready. After controlling active bleeders, wound was copiously irrigated with normal saline. Tetanus toxoid and intravenous ceftriaxone were administered while the patient was on resuscitation with fluids and blood. On stabilization, patient was taken to operating room where only full gross inspection of the wound was done under anaesthesia. 
Journal of College of Medical Sciences-Nepal,2011, Vol-7,No-1

The wound consisted of skin avulsions over right groin ,scrotum and penis with haematoma on anterior abdominal wall (fig-2). Both the corporal bodies were fractured along with partial cut injury on penile urethra. Active bleeding was due to vessels over groin and penile fracture. Some of the skin covering the injured area was still intact in the form of several flaps. There was no evidence of any bony injury (fig-2).

Extensive debridement of the macerated and devitalized tissue was done. Urethra was repaired and a foley catheter was placed. As microvascular surgery facility was not available both the corporal bodies were repaired using bucks fascia. Penis was buried under remaining scrotal skin and as the groin wound was contaminated it was left open to be covered later by split thickness skin graft (SSG)(fig3). Anterior abdominal wall haematoma was evacuated and primarily closed after hemostasis. After five days, groin wound was covered by SSG and after three weeks, penis was reconstructed with scrotal skin.(fig-4) The patient made uneventful recovery.

Patient told us that the same bear attacked his father 3 years back and bear attack was quite frequent in his area. According to him, it was 'KALO BHALU', the only species of bear found in that area. The beast was black in color with white patches over chest and face. He could also identify the beast (fig-1) among the photos of different species of bear shown to him.
Figure 1.

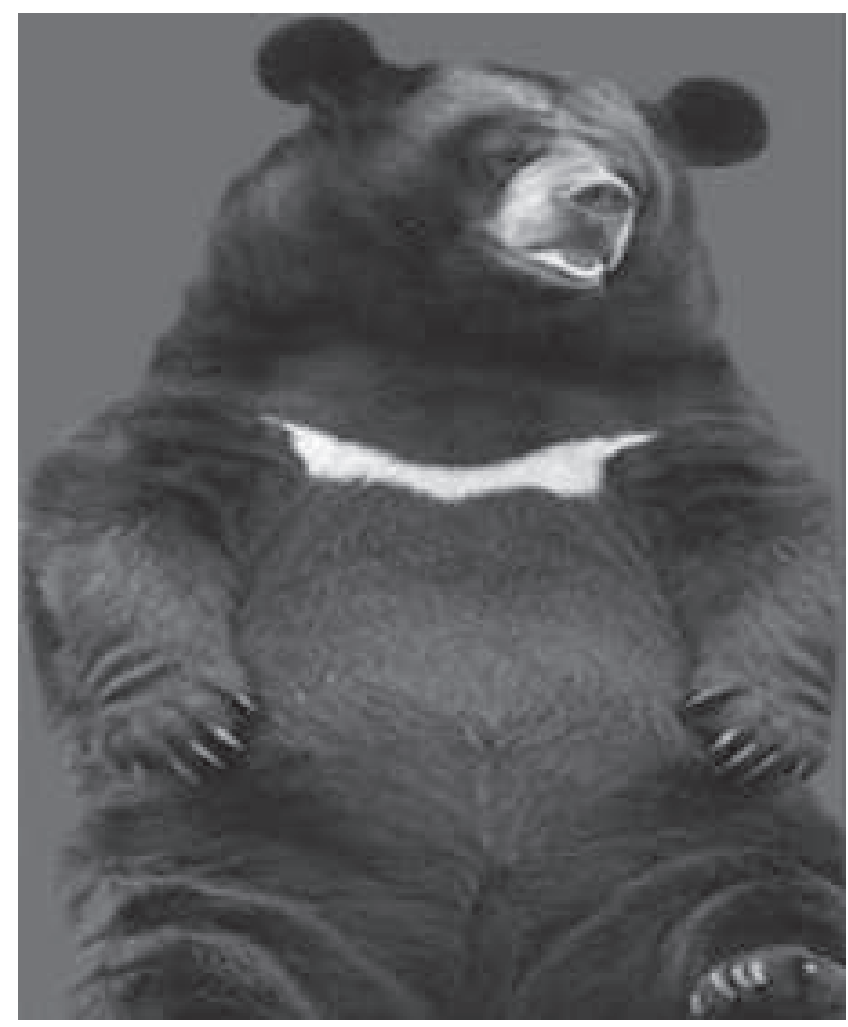

Figure 1: Asian black bear (Ursus thibetanus)

\section{Figure 2.}

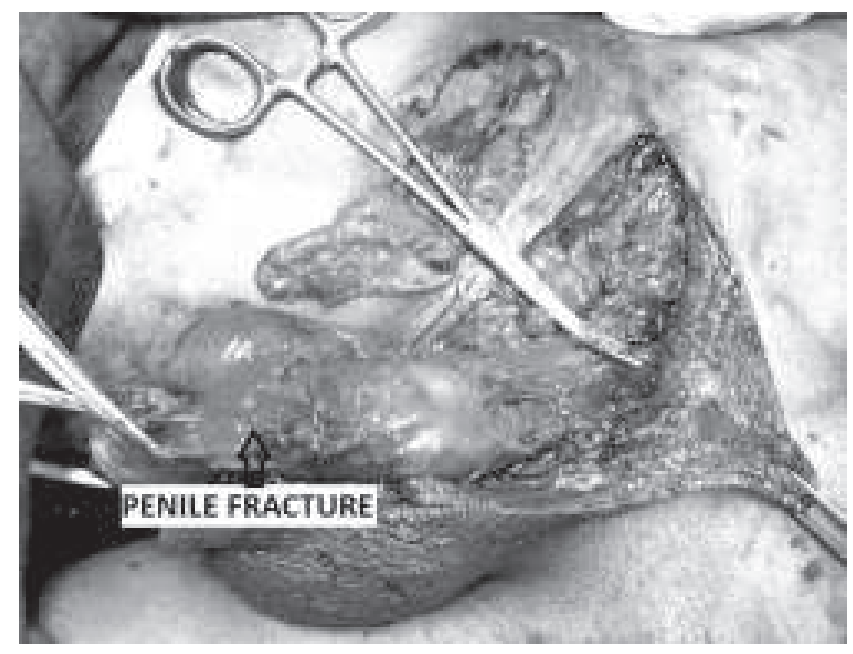

Figure 2: Bear attack causing genital injury(penile fracture) 
Figure 3.

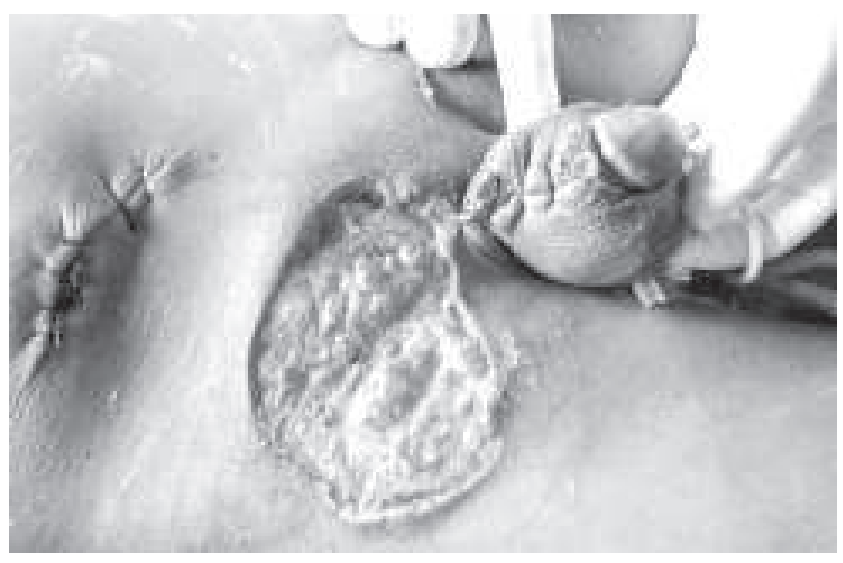

Figure 3: First stage management including debridement and repair of penile fracture with burying of penile shaft in scrotal skin

\section{Figure 4.}

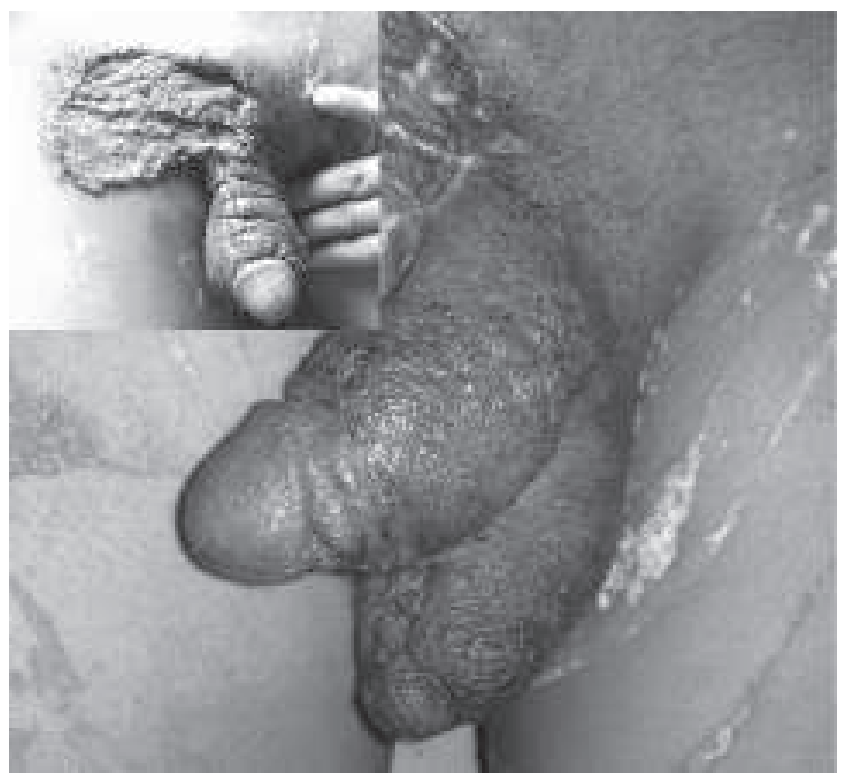

Figure 4: In stage two skin grafting and in stage three release of penis was done.

\section{Discussion}

Animal bite injuries are common and various animals, both domestic and wild have been reported to attack and bite humans. The great majority of attacks on people involve mammals, especially carnivores. ${ }^{1}$ The animals most commonly associated with assaults on humans are dogs and big cats. ${ }^{1}$ In Western countries, most animal bite wounds are inflicted by dogs and cats, dogs alone being responsible for up to $90 \%$ of these wounds. ${ }^{1}$ Majority of animal bite injuries are minor and only a small proportion of animal bite injuries lead to death. ${ }^{1}$ The main medical concern with animal bites is that the wounds are prone to get infected, requiring adequate antibiotic therapy and rabies prophylaxis., ${ }^{2,3}$

Wild animal attack, though rare, are distinguished by a combination of crushing and penetrating trauma and significant contamination from claws and teeth, which provide two distinct sources of infection. Although death from wild animal bites is uncommon, a significant number of people do die every year in attacks by large animals such as lions and bear. ${ }^{4}$ Humans assaulted by wild animals are at risk for both blunt and penetrating trauma as the creatures strike with their head or extremities, bite with powerful jaws and crush with their body weight. Puncture of body cavities and amputation of extremities can occur. ${ }^{4}$

Human injuries inflicted by bear attacks are uncommon because bears are generally tolerant of humans, and these injuries are rarely described in the literature..$^{5-7}$ Even more uncommon are fatal cases related to bear attacks. ${ }^{6-8}$ As noted by Tough and Butt ${ }^{8}$ fatal bear attacks seem to occur in one of three circumstances: a sudden encounter, the bear has a history of food conditioning and habituation 
or the bear's territory has been violated. A bear attack is typically a defensive measure to protect cubs, food cache or territory. In some cases of animal bites, the victims may have provoked the attack by their own behaviour. ${ }^{9,10}$ In our case also defence for territory seems to be the probable reason of attack.

Bear and human interactions have increased as the habitats of humans and wild animals have begun to merge. In literature almost all the injuries from bear attack were inflicted on the upper half of the body. This is because the victims try to defend themselves with their upper limbs when bear attack with forepaws. Our case is unique as major injured part was genitalia and groin region which is not found in any of our reviewed cases. All the victims in literature were attacked in isolation and never in groups as in our case.

Asiatic black bears (Ursus thibetanus) are medium sized bears, with adult males weighing $50-200 \mathrm{~kg}$ and adult females $40-125 \mathrm{~kg}$. They have more pronounced ears and a distinctive white or cream "V" on their chest. They are distributed through much of southern Asia, northeastern China, far eastern Russia and Japan. In the Indian sub continent, they are distributed in Afghanistan, Pakistan, India, Nepal and Bhutan. Currently, Asiatic black bears are distributed throughout the eastern to western ranges of hills and mountains of Nepal. They feed mainly on plants; however they also feed on insects, beehives, molluscs and other mammals when opportunity allows. Their food habits change seasonally and geographically.

The behaviour of bears varies according to species. Brown bear attack is often severe and sudden, without provocation. Grizzly bears when trapped or stimulated can be very dangerous. According to reports from various parts of the world, the majority of bear attacks have been committed by U. arctos. Black bear attacks usually result in minor injuries. ${ }^{8}$ In our case, the bear attacked its victim probably because the man unintentionally violated the territory of bear.

The case described here is unique in that most of the bear attack reported in literature have involved the upper half of body i.e face, scalp, shoulder, bones and chest etc. but in our case bear had attacked genital and groin region causing penile fracture and skin avulsions.

\section{Conclusion}

The victim of a bear-inflicted injury should be triaged as major trauma. Bear attack injuries involve upper half of the body predominantly and requires a team approach. Often management is staged, as damage control and infection control take precedence. Tetanus toxoid should be administered and public health authorities contacted, as to whether rabies immunization is required. The final result is often compromised by the nature of the trauma. People living in wilderness areas should avoid bear attacks by remaining in groups and restricting incursion into areas of likely conflict. 
A.Agarwal et al. Penile fracture caused by wild bear attack: A case report

\section{References}

1. H.C. Matter, S Arbeitsgemeinschaft. The epidemiology of bite and scratch injuries by vertebrate animals in Switzerland. Eur. J. Epidemiol 1998; 14: 483-90.

2. H.M. Feder Jr., J.D. Shanley, J.A. Barbera. Review of 59 patients hospitalized with animal bites. Pediatr. Infect. Dis. J. 1987; 6: 24-8.

3. C.K. Hermann, P.B. Hansen, J.M. Bangsborg, et al. Bacterial infections as complications of dog bites. Ugesk. Laeger 1998; 160 : 4860-3.

4. A. Abuabara. A review of facial injuries due to dog bites. Med Oral Patol Oral Cir Bucal 2006; 11: 34850.

5. T. Cardall, P. Rosen. Grizzly bear attack. J. Emerg. Med 2003; 24: 331-3.
6. T. Floyd. Bear-inflicted human injury and fatality. Wilderness Environ.Med 1999;10 : 75-87.

7. R.A. Dieter Jr., D.L. Dieter, R.A. Dieter, et al .Bear mauling: a descriptive review. Int. J. Circumpolar. Health 2001; 60: 696-704.

8. S.C. Tough, J.C. Butt. A review of fatal bear maulings in Alberta, Canada. Am. J. Forensic Med. Pathol.1993; 14 : 22-7.

9. F.M. Shattock. Injuries caused by wild animals. Lancet 1968; 1 : 412-5.

10. D.N. Durrheim, P.A. Leggat. Risk to tourists posed by wild mammals in South Africa. J. Travel Med.1999; 6 : 172-9. 